\title{
ANTROPOLOGIJA SIROMAŠTVA U KNJIŽEVNIM SVJETOVIMA VJENCESLAVA NOVAKA I KRLEŽINIM SOCIJALNIM FELJTONIMA
}

\author{
Suzana Marjanić \\ Institut za etnologiju i folkloristiku \\ Šubićeva 42 \\ HR 10000 Zagreb \\ suzana@ief.hr
}

UDK: 821.163.42.09Novak, V.

821.163.42.09Krleža, M.

Izvorni znanstveni članak

Ur.: 2020-4-30

Antropologija prosjačenja i ekohistorija zbirke Podgorske pripovijetke (1889.) Vjenceslava Novaka, gdje se često ističe antologijska Podgorska lutrijašica (Vijenac, 1889.), u odnosu na dijadu očevi/majke - kćeri/sinovi, dokumentira subalteran odnos iz pozicije časti prosjačkoga štapa u kojemu su roditelji pokvarenom smatrali djecu koja su se sramila prosjačenja.

U drugome dijelu članka navedena Novakova tematika antropologije prosjačenja i solidarnosti postavljena je u kontekst sa socijalnim feljtonima Miroslava Krleže. U tjedniku Narodna zaštita namijenjenom, prema atribuciji u podnaslovu, ratnim nemoćnicima $i$ siročadi, Krleža je 8. studenoga 1917. objavio feljton, kao svoj prvi članak o sirotinji, Kako stanuje sirotinja u Zagrebu? Drugi Krležin članak o sirotinji, feljton Narod koji gladuje, koji određuje kao varijantu o sijerku/metlama kojima se Hercegovci "hrane kao pogačom", pisan je na temu potresnih primjera strategija preživljavanja Hercegovaca koji su, u arealu borbi vlastitih izgladnjelih tijela, bili prisiljeni hraniti se sijerkom.

Ključne riječi: Vjenceslav Novak, antropologija prosjačenja - siromaštva, ekohistorija, Podgorska lutrijašica, zoosimbol pauk, Miroslav Krleža ${ }^{1}$

"Već pune tri decenije pogibaju naši talenti i padaju poraženi jedan za drugim, pre no što su uspjeli da izgrade svoj izraz i da svoj život formiraju dostojno, da bude u otmjenoj ravnoteži s njihovom dušom. Tako se srozao pod velikim teretom Novak, jadni školnik razdrt i rasparčan našim užasom. (...)."2

1 Ovaj je rad sufinancirala Hrvatska zaklada za znanost (Kulturna animalistika: interdisciplinarna polazišta i tradicijske prakse, IP-2019-04-5621).

${ }^{2}$ M. KRLEŽA, Slučaj kipara Studina, 1919. prema E. ČENGIĆ, 1985, 20. 


\section{Uvod}

Kritičar i esejist Marijan Jurković u monografiji o Vjenceslavu Novaku (1859. -1905.) zamjećuje da se priče o podgorskim prosjacima koje mu je Matica hrvatska objavila pod naslovom Podgorske pripovijetke (1889.) kao i one kasnije, ${ }^{3}$ s obzirom da se Novak vraćao navedenoj tematici, objavljuju i šezdesetih godina 20. stoljeća, no pridodaje da su ta izdanja "upućena jednom određenom čitaocu - đacima, koji po njima (misli se) treba da upoznaju Novaka."4 U okviru navedenoga ističe kako su umjetnički zahtjevne pripovijetke Po smrti i Slovo zakona. Ukratko, Jurković iz vlastite ideosfere socrealističke književnosti navodi kako su te podgorske teme "stranice s tezom o novcu koji siromahu može da donese jedino nevolje, patnje i propast, ili, pak, one druge koje su dane da bi bile ilustracija i apologija dogme o svetosti crkvenog i katoličkog braka."5

No, Novaka je, prije svega, zanimala dihotomija dvaju svjetova, antropološko pitanje zašto u svijetu postoji zlo. Tako je npr. romanom Dva svijeta (1901.) tematizirao dihotomiju svijeta umjetnosti i svijeta grube životne stvarnosti prelomljene kroz kalvariju glazbenika Amadeja Zlatanića, "hrvatskoga Mozarta"6. Riječ je o psihološkom romanu kao prvom pokušaju romana o glazbeniku, umjetniku u hrvatskoj književnosti. ${ }^{7}$ Dihotomija dvaju svjetova temeljna je odrednica i njegove podgorske tematika (kraj ispod Velebita južno od Senja) - dihotomija svijeta grube realnosti i svijeta imaginacije, kao što tematizira novela Podgorska lutrijašica (Vijenac, 1889.), na čijim će se svjetovima rad interpretativno zadržati.

Obično se navode Novakova četiri motivska kruga: dokumentarist Senja, pisac Podgorja ${ }^{8}$ dokumentarist hrvatskoga građanstva i malograđanstva,

3 Podgorskoj tematici Jurković pridružuje i roman Podgorka iz 1894. godine (M. JURKOVIĆ, 1962, 22). Za navedeni roman Krešimir Nemec ističe da je "ispod prosječne razine tadašnje romaneskne proizvodnje", a tome pridodaje i roman Pavao Šegota i roman Zapreke. (K. NEMEC, 1999, 225)

${ }^{4}$ M. JURKOVIĆ, 1962, 21.

${ }^{5}$ M. JURKOVIĆ, 1962, 22.

${ }^{6}$ K. NEMEC, 1999, 234.

${ }^{7}$ I u svom posljednjem romanu Tito Dorčić (1909.) Novak tematizira dihotomiju dvaju svjetova, sudbinu genijalnoga ribara s položenim ispitima za pravnika. Naime, Titu Dorčića jedino što je zanimalo u bečkoj kulturnoj ponudi bio je zoološki vrt, prvenstveno akvarij s ribama, rakovima i drugim morskim životinjama: "Od gradskog akvarija i ribnjaka Tito stvara svoj sretni prostor, male surogate svojega zavičaja, kap vode umjesto mora, oazu tišine i intimnoga zadovoljstva u stranom urbanom okruženju u koji je bačen protiv svoje volje." (K. NEMEC, 2010, 68).

${ }^{8}$ D. BABIĆ, 1984, 237. 
birokratskoga sloja (što dokumentira npr. u crtici Tko je to?, objavljenoj u Savremeniku 1919. $)^{9}$ te antropolog radništva. Antun Barac izdvaja i peti tematski krug, koji se odnosi na Novakove pjesme i priče za djecu, što ih je tiskao u Smilju, a koje je Hrvatski pedagoško-književni zbor nakon Novakove smrti objavio u zasebnoj knjizi, pod naslovom Iz života za život (1907.). ${ }^{10}$

\section{Podgorska lutrijašica - PTSP i simptom duševne patnje, submisivnost}

Kratak sadržaj Podgorske lutrijašice može se odrediti željom Podgorke Barice da spasi od zatvorske kazne "jadno dijete" Ernesta Lovrića, kojega je odgajala, a navedena je želja u opsesivnoj namjeri da dobije igru na sreću, na temelju odabrana tri "ne/sretna" broja, dovodi do ludila.

U predgovoru izdanju Podgorske lutrijašice iz 1945., izdanju koje je priredio Ferdo Pucek (kao i u prvom izdanju iz 1889.), Novak navodi da se, što se tiče djetinjstva, uvijek sjeća prosjaka Podgoraca, ističući u kontekstu antropologije tijela njihove tjelesne oznake: "Malo je koji dan minuo da nisam viđevao te bogalje odrpana odiela, snuždena lica, a nakažene tielom, kako su samo mogli smišljati."11 Nadalje bilježi kako su ih Senjani darivali kruhom i novčićem te da je u djetinjoj fantaziji zamišljao Podgorje "nekakim prosjačkim carstvom koje živi od tuđe milosti pod zemljom onako kako živu mravi u mravinjaku."12 Također u tom predgovoru bilježi kako je u odrasloj dobi boravio po mjesec i dva u podgorskim općinama i pješke je prošao to prosjačko, mravlje carstvo što mu je omogućilo i uvid u njihov život. Iz navedene perspektive dokumentira dvije vrste prosjaka - oni koji su iz "žive nevolje" prosjačili kao i oni koji su prosjačijom stekli lijep imetak. No, bez obzira na ovu drugu skupinu, ističe kako je malo tko od njih napustio Podgorje kada im je bilo ponuđeno da se presele u plodnu Slavoniju: "al malo se tko odvrgao od mora: zavolio je divlje prodole, grdne gudure, ljutu buru i bijesno more." ${ }^{13}$ Zamjetno je da rabi dvije zoometafore za njihov prosjački habitus: život kao mravi u mravinjaku (iz perspektive djetinjstva vlastitoga doživljaja

${ }^{9}$ U crtici Tko je to? Novak daje portret hrvatskoga malograđanina koji je pripadnik građanstva nesposoban za javnu djelatnost izvan svoga izravnoga interesa. Barac ističe da tom crticom Novak dokumentira i dobru karakteristiku malograđanina: "vidio je sve njegove mane - a ipak ga je volio!" (A. BARAC, 1968, 367)

\footnotetext{
${ }^{10}$ A. BARAC, 1968, 336.

${ }^{11}$ V. NOVAK, 1945, 6.

${ }^{12}$ V. NOVAK, $1945,6$.

${ }^{13}$ V. NOVAK, 1945, 6.
} 
Podgoraca), što se tiče njihova prosjačkoga habitusa, te ornitomorfnu metaforu u odnosu povratka slobodi mora pored njihova Podgorja: "od tuda se zalijeće u svijet kao ptica s gnijezda i vraća se opet u svoj goli kraj..."14 Zamjećuje kako je riječ o radinim ljudima te kako su u kamenoj pustoši ogradili ograde, iskrčili vinograde i zelenim listom nakitili mrtav kraj. Za razliku od navedenoga Novakova opisa Podgorja iz predgovora navedenoj zbirci novela, u kritičkoj literaturi obično se navodi sljedeći opis antropologije prosjačenja - siromaštva koji nije blizak Novakovu opisu. Antun Barac tako navodi da je Podgorje u svome siromaštvu, kao habitusu, stvorilo posebne pojmove moralu, časti i vlasništvu. Prosjačenje je bilo priznato zvanje, "pa se snaga kuće mjerila prema broju prosjačkih štapova (...). Pokvarenom su roditelji držali djecu koja su se stidjela prosjačiti". ${ }^{15}$

Iz Baričina govora iz pripovijetke Podgorska lutrijašica saznajemo da se cijelo njezino selo "tepe svijetom po prosjačiji" te, sâma navodi, da je njezin "krajprosjak", što se može upisatiu ekohistoriju ${ }^{16}$ krajolika koji socioekonomski određuje stanovnike - međuodnosi socioekonomske djelatnosti i prirodne sredine. ${ }^{17}$ Riječ je o kraju gdje "neće ni trn da raste"18. Socioekonomsku situaciju Podgorja Novak određuje društveno-političkim kontekstom; ističe da dok se ekonomski dizala Rijeka, propadao je Senj, a s njim i cijelo Primorje do Dalmacije. Šumu su pak iskorištavali stranci, a pritom su došle i Bečlije koji su na Velebitu (velebitska samoća) podigli zidane kuće: "sagradili ceste do mora i što je prije sjekla i pilila ljudska ruka, rezala je sada mašina i ljepše i brže na čudo domaćega svijeta."19

Nadalje, u okviru socioekonomije Novak u navedenoj noveli ističe kako je pomorac Lovrić među prvima nastojao dokazati da se samo zajednicom može odoljeti tuđincu, kolonijalizmu, u Khuenovoj eri, "koji je očigledce

${ }^{14} \mathrm{~V}$. NOVAK, $1889,6$.

${ }^{15}$ Barac navodi kako je najveću vlast predočavao financijski stražar u tome kraju koje je živjelo od prosjačenja i krijumčarenja. "Slabo plaćen, ne smijući se ženiti, 'financ' je za podgorsku djevojku ipak bio nekakav gospodin. Zaobilazeći odredbe o celibatu, takvi su ljudi ponajviše živjeli u divljim brakovima." (A. BARAC, 1951, 787; 1968, 334-335)

${ }^{16}$ Ekohistorija ili ekopovijest (povijest okoliša) proučava prošle ekosustave te povijest interakcije čovjeka i prirode. (usp. D. ROKSANDIĆ, 2018, 30-39)

${ }^{17}$ V. NOVAK, 1945, 16.

${ }^{18}$ V. NOVAK, 1945, 21.

${ }^{19}$ V. NOVAK, 1945, 44. Tako će u svojoj kulturološkoj enciklopediji velebitskoga kraja Šime Balen spomenuti i Vjenceslava Novaka da je dokumentirao u jednoj od svojih Podgorskih pripovijedaka Bečko društvo koje je početkom druge polovice 19. stoljeća započelo intenzivniju sječu velebitske šume. (Š. BALEN, 1999, 15) 
sjekao najljepšu šumu i pustošio krajeve, gdje si prije u gustoši čovjeka čuo, ali ni na dva koraka ne mogao se s njime sastati" ${ }^{20}$ Pored ekoshistorije, Novakova djela podgorske tematike mogu biti zanimljiva i kao tema plave humanistike, nove talasologije, studija oceana i otoka koja kao znanstvena područja i polja uključuju interpretaciju vode, mora iz književno-znanstvene vizure ${ }^{21}$, pri čemu se navodi sljedeći primjer opisa điskanja valova: "Nad olovnom bojom uzbibanoga mora điskalo bijelo valovlje, a krajem se valjao vjetar, kao da je pun gustih i tamnih para. Sa svih strana dizala se oluja za olujom, bio je to onakav zimski dan u Primorju kad te spopade neka jeza pred tajnim silama prirode, koje kao da će provaliti iz morskih dubina i grdnih oblačina što se valjaju mrtvim lijetom po nebu."22

Mirjana Trošelj, poznavateljica etnografije južnog Podgorja, zahvaljujući svojem stricu Ivanu (Ivici) Trošelju (1921. - 2012.), navodi kako je Novak dobro proučavao sela oko Jablanca, jablanački kraj te socijalne odnose prosjačenja toga kraja $\mathrm{s}$ frazom da se bogatstvo kuće u Podgorju mjerilo prema broju prosjačkih štapova.Nakon istraživanja antropologa Bojana Mucka (2009.) Mirjana Trošelj razgovarala je o navedenoj temi sa stricem koji je isto tako svjedočio da su prosjaci dolazili iz okolice Jablanca (predstavljali su se da su od Jablanca), no bilo ih je isto tako iz okolice Jurjeva (što nisu govorili). Iz srednjega Podgorja dolazili su podjednako iz brdskih naselja i naselja uz more u južno Podgorje na potezu od Lukova Šugarja do Selina. Stric se sjeća da su išli od kuće do kuće, štapali su se - imali su štap; dolazili su samo stariji, žene i muškarci, a u njegovu kuću, kad je stricu bilo desetak godina, dolazile su uglavnom žene i prosile vune i drugog prediva s napomenom: "Ćer mi se udaje, triba za dotu". Bili su poznati po prosjačkoj frazi "Daj mi, Bog ti da" po kojoj su ih Starigrađani Paklenički prozvali -"Evo, dolazi Daj mi, Bog ti da." I nadalje riječima Mirjane Trošelj: "Govorili su da dolaze iz okolice Jablanca, neki su govorili da dolaze iz Jurjeva (no oni su se sramili toga), svi su dolazili u prošnju, od Jablanca sve do Cesarice, a južno od Karlobaga nitko nije išao u prošnju. Osobito je srednje Podgorje bilo poznato po prosjačenju; nisu bili ribari, nisu imali zemlju, slabo stočarstvo u golom i suhom kršu pa su morali u prošnju. Sve se to održalo do Drugog svjetskog rata, a pamti se i krajem

${ }^{20}$ V. NOVAK, 1945, 44. U tome smislu nije u potpunosti točan Barčev sud o Novaku (usp. A. BARAC, 1968, 346) kao čovjeku koji "nije niti jednom jasnije zabilježio bilo kakvu crtu tadašnjeg protuhrvatskog režima Khuena Hédérvaryja." (prema J. DEROSSI, 1970, 63; 1981, 278)

${ }^{21}$ Usp. M. BREGOVIĆ, 2019, 239-240.

${ }^{22}$ V. NOVAK, 1945, 46. 
19. stoljeća. ${ }^{23}$ Tako je južno Podgorje bilo poznato po frazi "Daj mi, Bog ti da", dok je Bojan Mucko, koji je proučavao sjeverni i srednji dio Podgorja, zabilježio frazu "Podaj majko". ${ }^{24}$

Dok se na etnografskoj razini ocrtavaju dva tipa lokalne interakcije s prosjacima, od kojih je prvi bio određen regionalnim sustavom skrbi nad prosjacima, a drugi vezan uz prosjačku stigmatizaciju ${ }^{25}$, kod Novaka kao književnoga antropologa prosjačenja zamjetna je antropologija skrbi i solidarnosti s obzirom na njegov socijalni angažman, slično kao i u Krležinu slučaju, što će se dokumentirati u drugome dijelu rada. Podgorsku lutrijašicu (prvotno objavljenu u Vijencu 1889.) Novak otvara kronotopom 6. studenoga 188*. kada je karlovački vlak dojurio na Zagrebački kolodvor. Podgorka, starica oko šezdeset godina već je na kolodvoru opljačkana kada joj jedna neznana žena (tatica), kojoj se obratila za pomoć, krade dvadeset kilograma težak kovčeg (starica joj je prethodno dala željezničku predatnicu kojom je tatica otuđila kovčeg). Sveznajuća pripovjedačka instanca (heterodijegetski pripovjedač) staricu opisuje socijalnim statusom da je iz seoske bolje kuće, što dokumentira opisom njezine odjeće: "Tamno odijelo polugradskoga kroja i crni svileni rubac na glavi odavao je da je stara iz neke seoske, ali bolje kuće"26, pri čemu je istaknuto da govori primorskom štokavštinom. Zamjetno je da starica ima nekoliko poštapalica - "veseli" i "nebore". ${ }^{27,28}$

Sljedeće mjesto na kojemu starica boravi je krčma. Naime, nakon što je opljačkana, stražar joj pomaže da se smjesti u nekoj krčmici u gornjoj Ilici gdje je prospavala noć. ${ }^{29} \mathrm{Tu}$ Barica upoznaje studente od kojih saznaje da je "njezino dijete" Ernest Lovrić, zbog kojega i dolazi u grad, u zatvoru zbog pronevjere i krivotvorenja potpisa na mjenicama te ga državno odvjetništvo optužuje za zločinstva prevare i krađe te je osuđen je na kaznu od sedam godina

${ }^{23}$ Ivan Trošelj, prema kazivanju svoga djeda Mate Trošelja.

${ }^{24}$ Ulomak iz razgovora s kolegicom Mirjanom Trošelj 23. prosinca 2019.

${ }^{25}$ B. MUCKO, 2009, 257.

${ }^{26}$ V. NOVAK, 1945, 9.

${ }^{27}$ V. NOVAK, 1945, 16.

${ }^{28}$ Zamjetno je da Barica rabi odrednicu "crni bijes" za vlak, kada ističe da joj je to prvo putovanje željeznicom (V. NOVAK, 1945, 10). Nadalje buru, olujno nevrijeme na moru, heterodijegetski pripovjedač označava kao "živi bijes" u kojoj je stradao Baričin zaručnik Nikola (V. NOVAK, 1945, 34) ili pak kao "morski bijes" (V. NOVAK, 1945, 46). Sve završava Baričinim "igraćim bijesom" (V. NOVAK, 1945, 51) čime je i okončano njezino psihopatološko vjerovanje u numerologiju.

${ }^{29}$ V. NOVAK, 1945, 15. Antun Barac ističe kako je Novak prvi od hrvatskih književnika ulazio u gradske i predgradske krčme. (A. BARAC, 1968, 362) 
zatvora. ${ }^{30}$ Iz susreta sa studentima dokumentirana je u noveli i sociologija studiranja toga doba s obzirom na to da je riječ o generaciji sudaca i fiškala, što se i očekivalo od mladića toga doba. Iz susreta s njima u toj iličkoj krčmi motivirana je prva pripovjedačka analepsa (koja motivira njezin dolazak u Zagreb) iz koje saznajemo da je Barica bila svojta u Lovrićevoj kući: majku mu je othranila na prsima kao dojilja, a Ernesta je nosila na krst (krštenje). Nakon što je Ernestov otac umro, majka i on preselili su se u Zagreb, s obzirom na to da je želio biti sudac, no počeo je u raditi u pošti gdje i ostaje motiviran visokom plaćom. ${ }^{31}$ Tako se i drugi topos, iako nemjesto u Augéovu određenju ${ }^{32}$, očituje kao pomoćnik Barici. Dok joj je na kolodvoru stražar pružio pomoć da se pronađe kradljivica njezinoga kovčega, ovdje su pomoć organizirali krčmarica istudenti, prikupivši novac zanoćenje u Zagrebu te odlazak u posjet Ernestu Lovriću u zatvor.

Treći topos odnosi se na urbani okoliš Zagreba, Baričin doživljaj grada (drugo poglavlje novele motivira susret s Ernestom u zatvoru) kada odlazi iz iličke krčme prema sudu i zatvoru kao njezinim posljednjim zagrebačkim postajama na putu do "jadnoga djeteta" Ernesta. Heterodijegetski pripovjedač dokumentira njezin doživljaj urbanih fenomena kao prostora kojim ljudi prolaze ulicom kao procesijom: "s djetinjom radošću i čudom je motrila dva psa, upregnuta u malena kolica." ${ }^{33}$ Nadalje, dokumentiran je njezin doživljaj spomenika banu Jelačiću: "silan konj nasred trga, a na njemu čovjek digao u vis sablju" 34 , što sve čini zanimljive segmente za književnu antropologiju grada. ${ }^{35}$ Tek u zatvoru doznajemo njezino ime - Barica, kako je oslovljava Ernest, njezino "jadno dijete". Ivo Frangeš ističe kako je riječ o susretu u kojemu dvije osobe nemaju ništa zajedničko ${ }^{36}$ : "Četvrt sata projuri starici kao jedan čas, dok se Ernestu činilo da je starica već odavno tu."

Posljednji, treći dio novele odvija se u Podgorju (prostor Baričina habitusa nakon svih navedenih nemjesta), gdje Barica postaje lutrijašica kako bi Ernesta izbavila iz zatvora spregom moderne institucije (lutrija) i pradavne magije, praznovjerja. ${ }^{37}$ Prožimanje kršćanstva i pretkršćanske

\footnotetext{
${ }^{30}$ V. NOVAK, 1945, 19, 26.

${ }^{31}$ V. NOVAK, 1945, 18.

${ }^{32}$ Usp. M. AUGÉ, 2011.

${ }^{33}$ V. NOVAK, 1945, 23.

${ }^{34}$ V. NOVAK, 1945, 24.

${ }^{35}$ Usp. K. NEMEC, 2010.

${ }^{36}$ I. FRANGEŠ $, 1998,126$.

${ }^{37}$ I. FRANGES̆, 1998, 127.
} 
magije u modusu folklornoga kršćanstva ${ }^{38}$ donosi već prva scena posljednjega dijela novele: "Pred slikom Matere božje klečala je starica, a onda sjedne k stolu i nabroji devedeset zrna graška." ${ }^{39}$ Dok je premetala zrna graška, ugledala je pauka. Njegova je pojava, u kontekstu praznovjerja, za Baricu bila numinozna: pokušala je svojom lutrijom, graškom i paukom (gatanje pomoću graška, pauka i brojeva - devedeset zrna graška i devedeset brojeva) doći do nove životne stvarnosti - spasiti "jadno dijete" Ernesta. Rad navodi fragment koji se usredotočuje na numinoznu objavu pauka kao točke, velike crne piknje, kao Baričina usuda koji je prevrnuo tri njezine sudbonosne brojke pri prvom gatanju ${ }^{40}$ : "Najednom stane se tačka micati po stropu: velika, crna piknja pružila dugačke noge i pomicala se k starici. Kad je došla vrh njezine glave, stane i povuče tanke noge k debelomu tijelu. Starica gledaše i gledaše,vihor potrese kućom, a i stara se sva stresla, cijelim joj se tijelom prelio mrzao val." 41

Antun Barac navodi kako je u svim razdobljima Novakova života zamjetna "jaka zaliha misticizma i fatalizam - što se javlja u ljudi s lirskim naklonostima, nesposobnih da do kraja razumski dokuče istinu, makar i neprijatnu, pa da se bore s neprilikama." ${ }^{42}$ Smatra da misticizam i fatalizam u njegovim djelima nisu "uneseni iz knjiga, već da su proizašli iz piščeva bića". ${ }^{43}$ Folklorno vjerovanje tematizirano u noveli upućuje da ako pauk siđe sa stropa na osobu, prema numinoznoj snazi, ta će osoba dobiti veliki i neočekivani novac. ${ }^{44}$ Zbog toga Barica i uzima pauka, ili kao što navodi heterodijegetski pripovjedač - "nesretnu životinjicu", i zatvara ga u posudu (lonac) sa zrnima graška i numericama, njih devedeset (koje joj je ispisao susjed-dječačić s obzirom na to da je bila nepismena): "stara brzo prekrije lonac rupcem i sveže čvrsto oko oboda."45 I nadalje u toj enumeraciji duševne patnje lutrijašenja "Opet zasužnji pauka, ali

${ }^{38}$ Antropolog David F. Aberle rituale/magiju i religiju razlikuje s obzirom na prirodni i društveni okoliš te za magijske rituale navodi da nastoje uspostaviti kontrolu ljudi nad prirodom; npr. kontrola nad vremenom, povećanje uroda, ribe, lov ili postizanje zdravlja, dok za religijske rituale ističe da nastoje ukinuti društvene sukobe, zaštiti kodove ponašanja; nastoje popraviti društvene nemire. (usp. A. DE WAAL MALEFIJT, 1968, 14)

${ }^{39} \mathrm{~V}$. NOVAK, 1945, 30.

${ }^{40}$ Usp. B. SAX, 2001, 237.

${ }^{41}$ V. NOVAK, 1945, 31.

${ }^{42}$ A. BARAC, 1968, 368.

${ }^{43}$ A. BARAC, 1968, 368.

44 "Verovanja vezana uz pauka". Dostupno na: https://www.astro-tarot.rs/verovanja-zapauka/ (2020-3-13)

${ }^{45} \mathrm{~V}$. NOVAK, 1945, 32. 
nesretna životinjica radila bi sada previše, a sad premalo. Jedanput prevrnula jedan, drugi put dva, a treći put i deset brojeva."46

U toj navali simptoma duševne patnje Barica je prvo zamislila tri prikladna broja, "tri tužna broja, tri svjedoka žalosnih dana njezina života"47: $25,13,7$, koji su bitni za njezin život i kao takvi nose tragove nesreće. Odabirom tih brojeva, preko lutrije, odnosno numerologije, nastaju tri pripovjedačke analepse o Baričinu životu gdje saznajemo kako je bila vezana uz dvije obitelji - obitelj pokojnoga kapetana Pavelića i obitelj pokojnoga kapetana Lovrića. Broj 25 vezan je uz pogibiju, utapanje njezinoga zaručnika Nikole (25. prosinca, na Božić), nakon čega je odgajala i dojila kapetaničinu (kapetan Pavelić) ${ }^{48}$ djevojčicu Milku s obzirom na to da je Barica izgubila dijete u drugom mjesecu nakon poroda. $\mathrm{U}$ tome trenutku nastaje transfer ljubavi: s obzirom na gubitak zaručnika Nikole i djeteta, koje je rodila kriomice kući, "i kloneći se svijeta", i koje je očito zbog navedenoga i umrlo nakon dva mjeseca od poroda (što je dokument sociologije izvanbračne djece), Barica ostvaruje transfer ljubavi prema djevojčici Milki, "uživajući raskošnu sreću ljubeće matere, kad bi se na njezinim prsima igralo ručicama dijete i smiješilo joj se nevinim očicama draže i milije nego rođenoj majci." ${ }^{49}$ U tom odgoju, a u svojevrsnom stanju PTSP-a nakon gubitka zaručnika i (izvanbračnoga) djeteta, Barica se počela pretpostavljati i nad ulogom biološke majke - "(..) njoj se uopće činilo da to malo srdce nikoga ne pogleda tako ljubazno i milo kao nju $(\ldots) " .{ }^{50}$

Nadalje, broj 13 odnosi se na dan (13. veljače) kada je preminuo Ernestov otac (s kojim se Milka vjenčala) te slijedom toga Milka i "mali Ernest" (Baričino "dijete Ernest Lovrić") odlaze u Zagreb jer su Lovrićevu kuću i većinu imutka rasprodali vjerovnici. ${ }^{51}$ Broj 7 dvostruk je u svome udesu, a odnosi se na 7. listopada kada je Ernest osuđen zbog pronevjere na sedam godina. I lutrija Baricu dovodi do ludila ("igraćega bijesa") $)^{52}$. Život počinje određivati i prema oneiromantiji (pojavljivanjem određenih brojki u snovima) s obzirom na to da se nastoji domoći novca kako bi oslobodila

${ }^{46} \mathrm{~V}$. NOVAK, 1945, 50.

${ }^{47}$ V. NOVAK, 1945, 33.

${ }^{48}$ Obitelj kapetana Pavelića ujedno figurira i kao obiteljski dokument propadanja Senja kao trgovačkoga središta sredinom 19. stoljeća kada se uvode parni brodovi i počinju propadati senjski vlasnici jedrenjaka.

${ }^{49}$ V. NOVAK, 1945, 35.

${ }^{50} \mathrm{~V}$. NOVAK, 1945, 35.

${ }^{51}$ V. NOVAK, $1945,48$.

${ }^{52}$ V. NOVAK, 1945, 51. 
Ernesta, a sve u nadi kako bi je pozvao u Zagreb,što joj je i bilo obećano nakon smrti staroga Lovrića, Ernestova oca. Ludilo, simptom duševne patnje, "igraći bijes" označen je zoometaforom: "U staričinoj glavi rojili su se sami brojevi kao pčele u pčelinjaku, često bi usred noći ustala, pa da ne zaboravi brojke, što ih je snivala, odbrojila bi na stol tri hrpice graška, pa zorom poslala brojeve u Senj." ${ }^{13}$ Navedeno se može protumačiti Deleuzeovim i Guattarijevim razmatranjem o konceptu molekularnim postajanjem ${ }^{54}$, u konkretnom slučaju - molekularnim postajanjem navedenih triju brojki za koje Barica vjeruje da joj mogu promijeniti sudbinu. Počela je živjeti dvije paralelne stvarnosti, gdje ne postoji koncept pričina, prihvaćajući san kao realnost. Navedeno miješanje ontoloških razina dovodi Baricu do psihološkog gubitka razuma i sociološkog gubitka novca - postaje "prosjakinja pomućene pameti koja je prosila po gradu za krajcarak." ${ }^{55} \mathrm{U}$ tome smislu zoosimbol pauka kao Velike Majke u stravičnom vidu tkalje usuda ${ }^{56}$ dobiva dodatno na težini u Baričinu simptomu duševne patnje gdje je vlastiti život u sindromu ovisnosti podredila životima drugih, emotivno se vezujući uz "vlasnike", uz Milku i njezina sina Ernesta Lovrića. ${ }^{57}$ Određena traumom iz mladosti, nakon gubitka zaručnika i izvanbračnoga djeteta, emotivnim pričinom da pripada obitelji Lovrić, Barica psihopatološki troši ušteđevinu na lutriju kako bi pomogla Ernestu Lovriću, a zapravo samoj sebi kako bi se domogla Zagreba kao svojevrsne oaze, utopije slobode, ali i kao zone utišavanja PTSP-a jer bi ponovo mogla biti sa "svojom obitelji", u kojoj je određena habitusom služenja, lokusom submisivnosti, a koju je zadobila životnim gubitkom zaručnika i djeteta. U kontekstu navedenoga možemo primijeniti Geertzov konstativ opaukovoj mreži iz njegove definicije interpretativne antropologije - "Čovjek je životinja koja visi u paučini značenja koju je sam spleo." 58

${ }^{53}$ V. NOVAK, 1945, 57. Poznat je kontinuitet organiziranog priređivanja igara na sreću na području današnje Republike Hrvatske koji počinje još u vrijeme Austro-Ugarske u drugoj polovici 19. stoljeća. Što se tiče Ugarske u razdoblju od 1867. do 1918., Boris Kozjak ističe kako su posljednjih godina 19. stoljeća poznate igre na sreću toga doba bile u zenitu razvoja. (B. KOZJAK, 2016, 258) Novak u navedenoj noveli dokumentira kako je lutrija bila u Senju; riječ je dodatnom Baričinu naporu koja je u tom izazovu sreće dodatno plaćala "čovjeka koji je nosio za dva forinta u Senj na lutriju brojeve." (V. NOVAK, 1945, 49)

${ }^{54}$ Usp. G.DELEUZE - F. GUATTARI, 2013.

${ }^{55} \mathrm{~V}$. NOVAK, 1945, 52.

${ }^{56}$ J. C. COOPER, 1986, 126.

${ }^{57} \mathrm{~V}$. NOVAK, 1945, 48.

${ }^{58}$ C. GEERTZ, 1973, 310-323. 


\section{Krleža - Novak: antropologija solidarnosti}

O Novaku, našem zakašnjelom realistu, kojemu je kritika među svim značajnim piscima našega realizma posvećivala najmanje pozornosti ${ }^{59}$, Krleža ne bilježi mnogo. ${ }^{60}$ No, ono što bilježi pisano je iz niše prepoznavanja Novakove književne antropologije solidarnosti s poniženima i uvrijeđenima, s obzirom na to da ih, kao i Krležu i Kranjčevića, povezuje socijalna tematika proletarijata. ${ }^{61}$

Gotovo se u svim pregledima povijesti književnosti ističe da je Vjenceslav Novak opisivao sve društvene slojeve hrvatskoga društva druge polovice 19. stoljeća. Prvi je sustavno analizirao posljedice prvobitne akumulacije kapitala na moralnom planu; prvi se približio svijetu siromaštva, sirotinje, prosjaka i lumpenproletarijata; prvi je demaskirao hrvatskoga malograđanina u svim njegovim aspektima ${ }^{62}$ te je prvi uveo proletarijat u književnost ${ }^{63}$ - ušao je $u$ povijest hrvatske književnosti kao pjesnik sirotinje i obespravljenih. ${ }^{64}$ Barac ističe da je Novak od svih naših književnika, osim Kranjčevića, imao "najjači socijalni osjećaj koji ga je vodio sve bliže k ljudima na najnižim stepenicama. Zato ga još i za života nazvaše najboljim hrvatskim socijalnim piscem. (...) Taj dio Novakovih pripovijesti crpljen je iz Zagreba, iz siromašnih kućarica Radničkog dola, nekadanje Rokove ulice, Petrinjske i Vlaške itd., a njegovi su tipovi svi od reda izgrađeni na osnovi ličnih doživljaja." ${ }^{15}$ Nadalje Barac ističe da je Novak prvi od hrvatskih književnika "zapazio uzbune u glavama radnika i njihove težnje, da se otmu iz podređena položaja; prva svitanja u njihovim mozgovima i njihove spoznaje."66

U drugome dijelu ovoga članka navedena Novakova tematika antropologije prosjačenjai solidarnosti postavit će se u kontekst sa socijalnim feljtonima Miroslava Krleže iz razdoblja Prvoga svjetskog rata. Naime, u tjedniku Narodna zaštita namijenjenom, prema atribuciji u podnaslovu, ratnim nemoćnicima i siročadi, Krleža je 8. studenoga 1917. objavio feljton, kao svoj

${ }^{59}$ K. NEMEC, 1999, 226.

${ }^{60}$ Navedeno se može protumačiti zbog Novakove ideosfere; poznato je npr. da je Majstora Adama napisao po narudžbi Društva svetog Jeronima, "izdavačke kuće borbenih klerikalaca, a protiv socijalističke ideje." (M. JURKOVIĆ, 1962, 22)

${ }^{61}$ Usp. S. MARJANIĆ, 2018.

${ }^{62}$ K. NEMEC, 1999, 227.

${ }^{63}$ M. JURKOVIĆ, 1962, 22.

${ }^{64}$ I. FRANGEŠ, 1962, 7.

${ }^{65}$ A. BARAC, 1968, 336.

${ }^{66}$ A. BARAC, 1968, 362. 
prvi članak o sirotinji, Kako stanuje sirotinja u Zagrebu? ${ }^{67}$, koji je potaknuo groficu Elviru Kulmer da daruje Presvetlome 20.000 kruna: ${ }^{68}$ "To je od gospođe grofice zaista 'dirljivo', ali 'dirnuti' u srce jednoga Radivoja H.-a [Radivoj Hafner, op. S. M.] već je malo problematičnije. Kupio je Kalinovicu i Kerestinec, zaposlio čitavu grupu engleskih trenera (ratnih zarobljenika), njegovi engleski konji pobjeđuju u Beču i Pešti, kod njega večera čitav bečki generalitet."69 Pod datumom 12. veljače 1918. kao simbol znamenitih muževa naših dana Krleža postavlja karlovačkog mesara tipa Radivoja Hafnera, morskoga psa u Zagrebu i Beču, "koji stvara Historiju za besmrtne stranice Zlatne Knjige Naroda Hrvatskoga."70 Članak Kako stanuje sirotinja u Zagrebu?, u kojemu zoo-ontologemima metaforizira "bijesno, patničko, živinsko stradavanje" tisuće ubogara/žena "u strašno bijelom gradu Zagrebu" - "bolesnih zvijeri" koje žive u kuhinjama-daščarama ${ }^{71}$, kavezima u Radničkom dolu, na Potoku, u Kožarskoj ulici, na Srebrnjaku i na Kanalu, Krleža uokviruje profetskom opomenom kako je vrijeme "da se čuje jauk tih bolesnih i gladnih hiljada"72, Onih koji nemaju pravo na vlastitu Istinu.

Logika administrativnog procjenjivanja $\mathrm{u}$ konceptu Basaričekova human(itar)izma otvarala je paralelizam između života domobranskoga ratnoga invalida - pučkoga učitelja koji je triput ranjen, a procijenjen je vrijednošću od67 kruna mjesečno - i tržišne vrijednosti krave od 3.000 forinti: "(..) pita Visoki Naslov koliko mu vrijedi godišnja plaća u odnosu spram društvene i tržišne vrijednosti jedne krave?"73 Primjerice, početkom "oktobra" 1917. zapisuje kako Maričić, učitelj s Lošinja, želi posvojiti jedno hercegovačko dijete, bezimenoga sedmogodišnjega dječaka koji je od šoka, ugledavši truplo na vješalima, zanijemio te raskrinkava "veličajno-vrhunaravni" cinizam birokracije u okviru kojega nije bilo moguće pribaviti putovnicu za navedeno dijete kako bi otputovalo za Lošinj: "Izgubio sam na to čitavo prije podne bez uspjeha."74

${ }^{67}$ M. KRLEŽA, 1977a, 403-408.

${ }^{68}$ DD2, 133. U daljnjim navodima drugog izdanja Davnih dana (Dnevnik 1914-17: Davni dani I, Dnevnik 1918-22: Davni dani II) iz 1977. godine koriste se kratice DD i DD2. Ovdje se predstavlja sažeta verzija interpretacije spomenutih dvaju Krležinih novinskih članaka o antropologiji siromaštva tijekom Prvoga svjetskog rata (usp. S. MARJANIĆ, 2005).

${ }^{69} \mathrm{DD} 2,133$.

${ }^{70} \mathrm{DD} 2,56$.

${ }^{71}$ DD2, 404.

${ }^{72}$ DD2, 408.

${ }^{73}$ DD2, 114.

${ }^{74} \mathrm{DD}, 275$. 
Cinizam doktora Đure Basaričeka - a za kojega Krleža sarkastično dodaje da je riječ o oženjenom aktivnom katoliku koji "vodi grešnu ljubav sa gospođicom Vidosavom"75 - Krleža demaskira na slučaju petnaestogodišnje "curice"s kojom se njezin tutor nasilno-seksualno "poigrao" i na primjeru indiferentnosti navedenoga nositelja hrvatskoga human(itar)izma: "Vidite, zatrudnjela je, znači, nije bila baš 'curica', i zašto bi se ta stvar dramatizirala tako 'futuristički'?"76

Drugi Krležin članak o sirotinji, feljton Narod koji gladuje, koji određuje kao "varijantu" o sijerku/metlama kojima se Hercegovci "hrane kao pogačom", pisan je na temu potresnih primjera strategija preživljavanja Hercegovaca koji $\mathrm{su}, \mathrm{u}$ arealu borbi vlastitih izgladnjelih tijela, bili prisiljeni hraniti se sijerkom. ${ }^{77}$ Članak je trebao biti objavljen u Hrvatskoj njivi 1. prosinca 1917.78, ali je tekst zaplijenjen (na mjestu teksta nalazi se bijela površina). ${ }^{79}$ Početak i kraj članka Krleža uokviruje perlokucijskom opomenom kao oporukom Onih koji umiru od gladi - "Dalmacija, Bosna, Hercegovina, Lika, Primorje, Istra, umiru od gladi!"80 - koju upućuje kao korektivnu etičku pljusku ethosu human(itar)izma zagrebačke "zrakoplovne inteligencije"81, razotkrivajući pritom prijestolnicu

${ }^{75} \mathrm{DD} 2,130-131$.

${ }^{76} \mathrm{DD} 2,130$.

${ }^{77} \mathrm{DD} 2,133$.

${ }^{78}$ DD2, 409-413.

${ }^{79}$ Usp. Krležijana 2, 72. U samom članku Narod koji gladuje - koji jetiskan u knjizi Moj obračun s njima (Zagreb, 1932, vlastita naklada) i u Dodatku drugog izdanja Davnih dana - ne navodi se "sijerak/metla" već "slamnjače, korijenje i trava" (usp. DD2, 410). U zapisu Iza kulisa godine 1918 (slobodnim neupravnim govorom) bilježi kako je članak - koji je trebao biti objavljen u Obzoru- o sijerku (metlama) kojim se "Hercegovci hrane kao pogačom (...) mudra cenzura zaplijenila, a poslije toga došlo je do scene u 'Obzoru': kako se smjelo to štampati kad je to očito provokacija." (DD2, 133) U knjizi Moj obračun s njima upućuje na to da je u Obzoru objavio članako sijerku,kako su Hercegovci imenovali kruh samljeven od "drožđa"("drožd, droždina, od masti i od drugog koječega ono što ostane na dnu kao gad, talog, trop") i otpadaka"koji glođe Hercegovina kao blagdanju pogaču" (Krleža 1988/1932, 233). Povodom članka o sijerku koji je, prema Krležinu navodu u zapisu Iza kulisa godine 1918, objavljen u Obzoru Davor Kapetanić zaključuje: "(...) kako pak o tome nema nikakvih tragova na stranicama samog 'Obzora', opravdanije je pretpostaviti da je i taj članak brisan još u predcenzuri." (Bibliografija, 1999, 9)

Pod datumom 27. studenoga 1917. zapisuje: "Fra Didak (Buntić) piše da će pola Hercegovine pod ledinu. Melju ljudi sijerak i peku hljeb od sijerka. Pojeli su sve vrapce." (DD, 343 [usp. M. VAUPOTIĆ, 1964, 25]) Fra Didak Buntić vjerojatno je "jedan franjevac iz Hercegovine" čije pismo Krleža citira u članku Narod koji gladuje kojim upozorava: "Lani sam ih pokapao na stotine, a ove ćemo ih godine na hiljade." (prema DD2, 411). O suradnji Basaričeka s fra Didakom Buntićem usp. M. KOLAR-DIMITRIJEVIĆ, 1997, 87.

${ }^{80}$ usp. DD2, 409-413.

${ }^{81} \mathrm{DD} 2,410$. 
Trojedne kraljevine kao "grozno Potemkinovo selo". ${ }^{82} \mathrm{U}$ navedenom članku Krleža interpolira molbenicu Luce Pajdaković koja se obraća "i na samu vladaricu", nadajući se novčanoj potpori za sebe i sina budući da joj je muž u funkciji "prvosvjetskoratnog" Odiseja na ratištu. Istu molbenicu patnje - za koju u podrupku zapisa bilježi da ostavlja "nepromijenjen tekst" molbe ${ }^{83}$ - Krleža uvodi i u zapis Iza kulisa godine 1918. ${ }^{84} \mathrm{U}$ članku Narod koji gladuje spomenutu molbenicu završava komentarom: "Ime i veliki krst, jer ta mati ne zna pisati!"85

Pod datumom 1. prosinca 1917, "u 9 sati prije podne" bilježi recepciju svoga članka o socijalnoj bijedi: "- Kako će se sve to svršiti, što ja mislim, zaustavio me je jutros dr D. S. vrlo ljubazno, upravo u vezi s nekim mojim tekstom o socijalnoj bijedi kao takvoj, o bijedi za koju se ne bi moglo reći da ne raste iz dana u dan. Čovjek je pacifist. Nema više kakaa, ni maslaca, ni biskvita, a putovati se uopće više ne može. Ukinuta su kola za spavanje. Konac svijeta." ${ }^{86}$ U dnevničkom zapisu 30. studenoga 1917, "poslije podne u 6 sati" zapisuje da u redakciji Hrvatske njive očekuje povratak špalta sa cenzure te da je cenzura izbrisala "samo sijerak hercegovački. Inače je prošlo sve." ${ }^{87} \mathrm{U}$ zapisu Iza kulisa godine 1918 bilježi da se zbog članka Narod koji gladuje, zabranjenog u Hrvatskoj njivi, nisu uzrujali ni "vitez" Juraj Demetrović ni Dragutin Prohaska: "To su politikanti koji računaju s danima koji dolaze." 88 Porazno stanje iza ratnih kulisa, prema Krležinim analizama, razotkriva "sto-dvjesta hiljada ratnih zarobljenika, sto pedeset hiljada udovica, Zeleni kader harači na sve strane, zemlja skapava od gladi." 89 Nasuprot onodobnim sociološkim analizama, čija se human(itarn)a strategija zadovoljavala postavljanjem pitanja o sociologiziranim shemama žrtava ${ }^{90}$, Krleža se očituje kao "glas saveza"s ubogarima "iza ratnih kulisa", imperativno zahtijevajući human(itarn)u akciju iz moralne perspektive "sada, ovoga trenutka". ${ }^{11}$ Jer"(...) kada su hercegovačke krave već popasle sve

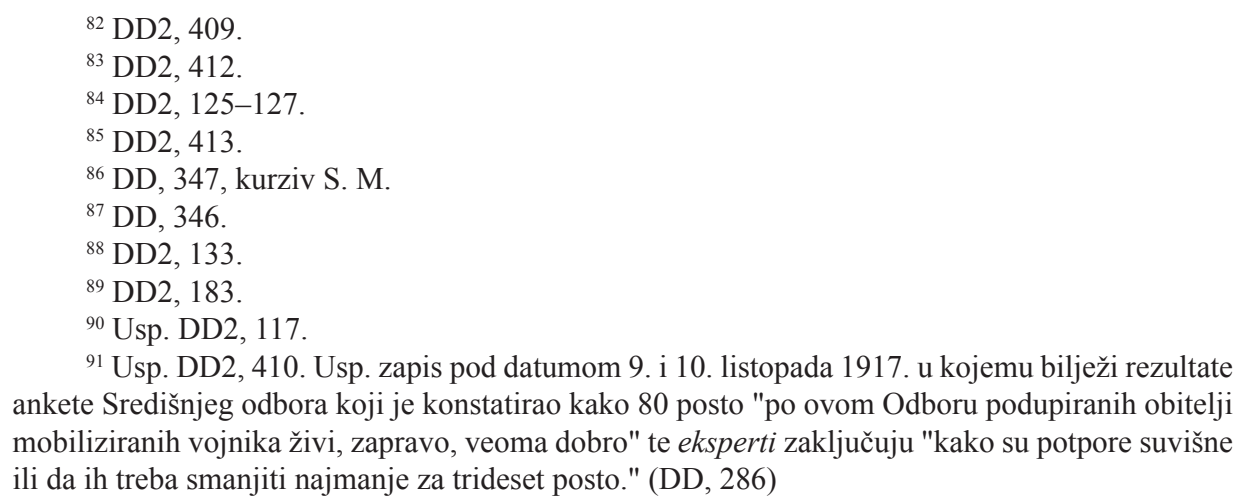

${ }^{91}$ Usp. DD2, 410. Usp. zapis pod datumom 9. i 10. listopada 1917. u kojemu bilježi rezultate ankete Središnjeg odbora koji je konstatirao kako 80 posto "po ovom Odboru podupiranih obitelji mobiliziranih vojnika živi, zapravo, veoma dobro" te eksperti zaključuju "kako su potpore suvišne ili da ih treba smanjiti najmanje za trideset posto." (DD, 286) 
slamnate strehe dokle su mogle da ih dosegnu, odlučio se naš svijet da pokusa sve behaerarske metle." ${ }^{92} \mathrm{U}$ spomenutim novinskim člancima Krleža subvertira mitem o bijelom gradu Zagrebu - o strašno bijelom gradu Zagrebu ${ }^{93}$ - njegovom purgersko-indiferentnom etikom "Ah, kaj! Se bu dobro!"94, "kumečkom" filozofijom i folklorističnim narodom na Harmici "pod repom svoga bana."95 Koliko je iskreno i socijalno motiviran Krležin angažman u opomeni o patnji stradalnika iza ratnih kulisa, pokazuje to što je u memoarskom zapisu Iza kulisa godine $1918 .{ }^{96}$ ponovno aktualizirao problematiku prvosvjetskoratnoga human(itarn)og cinizma, kontrapunktirajući diskurz obitelji mobiliziranih i u ratu poginulih vojnika s diskurzom cinizma moći na vlasti gospodina Šefa Đure Basaričeka, za kojega su svi ljudi "koji ne vjeruju u Stipu ${ }^{97}$ - futuristi"98. Viktor Žmegač konstatira da je dovoljno usporediti zapis Iza kulisa godine $1918 \mathrm{~s}$ navedenim dvama novinskim člancima (članke Krleža uvodi u Dodatku Davnih dana), "koji sadrže posve istu građu, samo u konvencionalnijoj publicističkoj fakturi. Posrijedi su, zapravo, varijante intencionalnog teksta, koji se može suponirati." ${ }^{199}$ Aktualni mentalitet hijerarhijske činovničke human(itarn)e svijesti što se očituje kao Hermes legislativa vladajuće ciničke svijesti, pred čijim vratima stoje Oni koji su smješteni radikalno Dolje, Krležu uvodi u razmatranje sveprisutnog fenomena cinizma.

Dokumentarnost svjedočenja o cinizmu human(itar)izma iza ratnih kulisa Krleža legitimira interpolacijom životopisa "običnih ljudi". Za obitelji "legendarnih junaka" život u pozadini, iza ratnih kulisa, sveo se na taktike preživljavanja pred aprovizacijom ${ }^{100} \mathrm{i}$ ovisi o odlukama predstavnika "carske i zemaljske" vlasti, čija moć počiva na kalkuliranju s postojećim sredstvima. I dok propagatori ratnoga inzulta svakodnevno proizvode ratničke i svetačke slogane o junačkom ascensusu "legendarnih junaka" na ratištu, istodobno nastoje prikriti descensus njihovih obitelji, silazak smrti u život. Krleža poput antropologa svakodnevice i mikrohistoričara sa subverzivnom aurom razmatra pojedine slučajeve života-strave te oblikuje sliku o cjelini iza ratnih

${ }^{92} \mathrm{DD} 2,133$.

${ }^{93} \mathrm{DD} 2,404$.

${ }^{94} \mathrm{DD} 2,410$.

${ }^{95} \mathrm{DD} 2,305$.

${ }^{96}$ Zapis Iza kulisa godine 1918 (Republika, 1967, 7-8) Krleža uvodi u drugo izdanje Davnih dana.

${ }^{97}$ Stjepan Radić (op. S. M.)

${ }^{98} \mathrm{DD}, 291$.

${ }^{99}$ V. ŽMEGAČ, 1988, 43. Usp. Krležijana 1, 154.

${ }^{100}$ Usp. DD2, 405. 
kulisa 1918. godine: "Stanuju u zahodima i piju iz tih istih zahoda svoju vlastitu vodu. (...) Drago Čanađi, pet godina, uhapšen pred 'Corsom'. Stanuje Županijska ulica osam. Otac podvornik, mlati ga kao pseto ne donese li kući barem sedam kruna dnevno. Majka leži od upale pluća." ${ }^{101}$

Zaključno o književnim dokumentima antropologije solidarnosti $i$ siromaštva: Novak - Krleža

Svjedočenje o svakodnevici ratne "pozadine" koja je postala izvanredna, izglobljena, izjednačena sa životom-stravom Krleža je bilježio u publicističkim i dnevničko-memoarskim zapisima te njihov historiografski materijal transponirao u književnoumjetnički diskurz.

Kontrapunktira makrohistorijsku dimenziju interpretacija upisanoglorifikacijske povijesti, koja se usredotočuje na društvene strukture moći i procese i individualnu dimenziju povijesti na kojoj se artikuliraju pojedine ljudske akcije Onih koji stoje pred vratima državnih institucija i za koje je kinizam $^{102}$ najčešći (jedini mogući) oblik odnosa prema cinizmu moći, upravo kao što je Vjenceslav Novak krajem 19. stoljeća, u realističkoj recepturi, književno dokumentirao antropologiju prosjačenja, siromaštva i radništva, svih onih segmenta koji vode prema današnjem habitusu prekarijata. ${ }^{103}$

\section{Literatura}

\section{Izvori}

Miroslav KRLEŽA, Dnevnik 1914-17: Davni dani I., Sarajevo, NIŠP Oslobođenje, 1977.

Miroslav KRLEŽA, Dnevnik 1918-22: Davni dani II., Sarajevo, NIŠP Oslobođenje, 1977a.

Krležijana 1 A-LJ, Zagreb, Leksikografski zavod Miroslav Krleža, 1993.

Krležijana 2 M-Ž, Zagreb, Leksikografski zavod Miroslav Krleža, 1999.

Vjenceslav NOVAK, Podgorske pripovijetke, Zagreb, Matica hrvatska, 1889.

Vjenceslav NOVAK, Podgorska lutrijašica, Zagreb, Galebovi, 1945.

${ }^{101} \mathrm{DD}, 300$.

${ }^{102}$ Usp. P. SLOTERDIJK, 1992.

${ }^{103}$ O usporedbiknjiževnoga svijeta Novakove novele Jerko Dropalos nadimkom Dobričak s Krležinom dramom U logoru usp. J. DEROSSI, 1970. 


\section{Knjige i članci}

Marc AUGÉ, Nemjesta ili Uvod u moguću antropologiju supermoderniteta, Karlovac, Društvo arhitekata, građevinara i geodeta, 2011.

Dragomir BABIĆ, Podgorska dimenzija Vjenceslava Novaka, Senjski zbornik, 10-12, Senj, 1984, 239-245.

Antun BARAC, Vjenceslav Novak (1859-1905), Republika: časopis za književnost $i$ umjetnost, 11-12, Zagreb, 1951,785-797.

Antun BARAC, Književnost Istre i Hrvatskog primorja, Zagreb, Rijeka, Matica hrvatska, 1968.

Šime BALEN, Velebit se nadvio nad more...: putopisni zapisi s planine, Zagreb, Planinarsko ekološko društvo Duga, 1999.

Monika BREGOVIĆ, Konferencija Sea Change: Wavescapes in the Anthropocene, organizaciji Sveučilišta u Splitu, Split, Komiža, 3.-6. prosinca 2018., Narodna umjetnost, 56, Zagreb, 2019, 239-240.

Jean Campbell COOPER, Ilustrovana enciklopedija tradicionalnih simbola, Beograd, Prosveta-Nolit, 1986.

Enes ČENGIĆ, S Krležom iz dana u dan (1975. -1977.). Trubač u pustinji duha, Zagreb, Globus, 1985.

Julije DEROSSI, Prilog ocjeni stvaralaštva Vjenceslava Novaka, Umjetnost riječi, 1-2, Zagreb, 1970, 61-66.

Julije DEROSSI, Iz ostavštine Vjenceslava Novaka, Senjski zbornik, 8/1, Senj, 1981, 277-292.

Ivo FRANGEŠ,Vjenceslav Novak danas, Riječka revija, 3-4, Rijeka, 1962, 1-10.

Ivo FRANGEŠ - Viktor ŽMEGAČ, Hrvatska novela: interpretacija, Zagreb, Školska knjiga, 1998.

Clifford GEERTZ, The Interpretation of Cultures, New York, Harper Collins Publishers, 1973.

Gilles DELEUZE - Félix GUATTARI, Kapitalizam i shizofrenija 2: Tisuću platoa, Zagreb, Sandorf \& Mizantrop, 2013.

Marijan JURKOVIĆ, Vjenceslav Novak, Beograd, Izdavačko preduzeće Rad, 1962.

Mira KOLAR-DIMITRIJEVIĆ, Prilog poznavanju života i rada radićevca i humanitarca dra Đure Basaričeka (1884. -1928.), Podravski zbornik 23, Koprivnica, 1997, 85-98.

Boris KOZJAK, Kockanje: od dokolice do socijalne patologije: sociološki aspekti, Zagreb, TIM press, 2016.

SuzanaMARJANIĆ, Glasovi "Davnih dana": transgresije svjetova u Krležinim zapisima 1914-1921/22, Zagreb, Naklada MD, 2005.

Suzana MARJANIĆ, Kranjčevićevi socijalni topoi - od Krležine interpretacije do suvremenoga aktivizma/artivizma, u: Zbornik radova 1. Senjskog interdisciplinarnog simpozija "Zdravo ste nam, braćo, u kamenu Senju! (nova čitanja)", Ana Vukelić (ur.), Senj, Grad Senj, 2018, 80-93.

Bojan MUCKO, Podaj majko - semiotička analiza podgorskog identiteta, Senjski zbornik, 36, Senj, 2009, 275-300. 
Krešimir NEMEC, Povijest hrvatskog romana od početaka do kraja 19. stoljeća, Zagreb, Znanje, 1999.

Krešimir NEMEC, Čitanje grada: urbano iskustvo u hrvatskoj književnosti, Zagreb, Naklada Ljevak, 2010.

Drago ROKSANDIĆ, Čovjek i prostor, čovjek u okolišu: [ekohistorijski ogledi], Samobor, Meridijani, Društvo za hrvatsku povjesnicu: Centar za komparativnohistorijske i interkulturne studije, 2018.

Boria SAX, The Mythical Zoo. An Encyclopedia of Animals in World Myth, Legend, \& Literature,Santa Barbara, California - Denver, Colorado - Oxford, England, ABC-CLIO, 2001.

Peter SLOTERDIJK, Kritika ciničkoga uma, Zagreb, Globus, 1992.

Miroslav VAUPOTIĆ, Socijalni smisao Krležina djela, u: Krležin zbornik, Ivo Frangeš i Aleksandar Flaker (ur.), Zagreb, Naprijed, 1964,19-36.

Annemarie DE WAAL MALEFIJT, Religion and Culture. An Introduction to Anthropology of Religion, Long Grove, Waveland Press Inc., 1968.

Viktor ŽMEGAČ, Krležina dnevnička proza, Umjetnost riječi, 1, Zagreb, 1988, 39-53.

\section{Internetski izvori}

https://www.astro-tarot.rs/verovanja-za-pauka/ (2020-3-13)

\section{THE ANTHROPOLOGY OF POVERTY IN THE LITERARY WORLDS OF VJENCESLAV NOVAK AND KRLEŽA'S SOCIAL FEUILLETONS}

\section{Summary}

The anthropology of begging and eco-history of the collection Podgorske pripovijetke (Podgorje Stories) (1889) by Vjenceslav Novak, where the anthological Podgorska lutrijašica (Podgorje Lottery Seller) (Vijenac, 1889) stands out, in relation to the dyad of father/mother daughter/son, documents a subaltern relationship from the position of the honour of begging in which parents considered children corrupt who were ashamed of begging.

In the second part of the article, Novak's mentioned theme of the anthropology of begging and solidarity is placed in context with the social feuilletons of Miroslav Krleža. In the weekly publication Narodna zaštita (National Protection) intended, according to the attribution in the subtitle, for the wartime helpless and orphans, Krleža published a feuilleton on $8^{\text {th }}$ November 1917, as his first article about the poor, How do poor people in Zagreb live?

Krleža's second article about the poor, the feuilleton Narod koji gladuje (The hungry people), which he defines as a variant about the sorghum/Osyris alba which Herzegovinians"fed on like flatbread", is written on the theme of the shocking examples of the survival strategies of the Herzegovinians who were, in the area of the struggle of their own starving bodies, forced to eat sorghum.

Keywords: Vjenceslav Novak, anthropology of begging - poverty, eco-history, Podgorska lutrijašica, living symbol spider, Miroslav Krleža 